\title{
KITAB KUNING DAN TRADISI INTELEKTUAL NAHDLATUL ULAMA (NU) DALAM PENENTUAN HUKUM (Menelisik Tradisi Riset Kitab Kuning)
}

\author{
Ali Mutakin \\ Sekolah Tinggi Agama Islam (STAI) Nurul Iman Parung-Bogor \\ Jl. Nurul Iman No. 01 Ds. Warujaya Rt. 01/01 Kec. Parung Kab. Bogor \\ e-mail: nabilamandor@gmail.com
}

\begin{abstract}
Abstrak: Artikel ini merupakan hasil penelitian kepustakaan (library reseach), dengan mengambil tema Kitab Kuning dan Tradisi Intelektual Nahdlatul Ulama (NU) dalam Penentuan Hukum: Menelisik Tradisi Riset Kitab Kuning. Ada dua pertanyaan yang diajukan dalam artikel ini, 1) Bagaimanakah kedudukan Kitab Kuning dalam tradisi intelektual Nahdlatul Ulama, 2) Bagaimanakah rumusan metode Nahdlatul Ulama dalam penentuan hukum. Kesimpulannya adalah bahwa Nahdlatul Ulama (NU) sebagai organisasi sosial keagamaan, memiliki hubungan yang erat dengan keempat mazhab fikih (mazhab Hanafi,Maliki, Syafi'i dan Hambali). Hal ini berimplikasi terhadap ketergantungannya pada kitab kuning sebagai basis intelektual yang turun temurun. Ketergantungan pada kitab kuning dalam aktifitas intelektualnya lebih disebabkan pada asumsi bahwa perpindahan ilmu agama Islam tidak boleh terputus dari satu generasi ke generasi berikutnya atau matarantai (sanad) ilmu agama Islam harus diketahui dengan baik dan benar. Sedangkan tradisi risetnya, NU menggunakan tiga metode Pertama, metode taqrî̀r jamầi (penetapan hukum secara kolektif). Kedua, metode ilhâa al-masâil bi nadhâ'irihâ. Prosedur ini digunakan untuk menggantikan istilah qiyas, yang menurut pandangan NU tidak layak dan tidak patut dilakukan, karena qiyâs merupakan suatu kompetensi yang hanya dimiliki oleh seorang mujtahid. Ketiga, metode istinbât yaitu secara bersama-sama mepraktikkan qawâid usyûliyyah dan qawâid fiqhiyyah sebagaimana yang telah dirumuskan oleh para mujtahid terdahulu.
\end{abstract}

\section{Kata kunci: NU, Kitab Kuning, Tradisi Intelektual, Metode Riset.}

Abstract: This article is the result of library research (library reseach), taking the theme of the Yellow Book and the Intellectual Tradition of Nahdlatul Ulama (NU) in Determining Law: Researching the Yellow Book Research Tradition. There are two questions raised in this article, 1) What is the position of Kitab Kuning in the intellectual tradition of Nahdlatul Ulama, 2) What is the formulation of the Nahdlatul Ulama method in determining the law. The conclusion is that Nahdlatul Ulama (NU) as a socio-religious organization has a close relationship with the four schools of fiqh (Hanafi, Maliki, Syafi'i and Hambali schools). This has implications for its dependence on yellow books as a hereditary intellectual base. Dependence on the book of yellow in intellectual activity is more due to the assumption that the transfer of knowledge of Islam should not be interrupted from one generation to the next or the chain (sanad) of the knowledge of Islam must be known properly and correctly. As for the research tradition, NU uses three methods. First, the method of taqriiir jamâ'i (collective law setting). Second, the method of ilhâq al-masâil bi nadhâ'irihâ. This procedure was used to replace the term qiyas, which according to NU view was inappropriate and not feasible, because qiyas was a competency that only a mujtahid possessed. Third, the istinbât method, which jointly practices the usyûliyyah and qawaid fiqhiyyah qawâid as formulated by earlier mujtahids.

Keywords: NU, Kitab Kuning, Intellectual Traditions, Research Methods. 


\section{Pendahuluan}

Pada dasarnya kegiatan ijtihad adalah pengerahan segala kemampuan oleh seorang mujtahid dalam rangka memperoleh hukum syar'i yang bersifat praktis ('amali) melalui jalan istinbâth.

Kata mujtahid, dalam pengertian di atas, menunjukan bahwa kegiatan ijtihad harus dilaksanakan oleh orang yang mempunyai kreteria atau pangkat mujtahid, ${ }^{1}$ tidak semua orang boleh melaksanakan kegiatan tersebut. Sedangkan untuk memperoleh pangkat mujtahid diperlukan sejumlah syarat yang telah ditetapkan oleh jumhur 'ulama.

Nahdlatul Ulama (NU) mempunyai istilah tersendiri untuk jenis kegiatan tersebut, karena bagi komunitas NU, kegiatan ijtihad adalah merupakan hak otoriter para imam mazhab, karena merekalah yang mempunyai kualifikasi keilmuan sebagai mujtahid mustaqil atau mujtahid mutlak.

Nahdlatul 'Ulama yang berarti kebangkitan para 'ulama merupakan sebuah organisasi keagamaan yang didirikan oleh sejumlah tokoh 'ulama dan usahawan di desa Kertopaten Surabaya pada tahun 1926

${ }^{1}$ Imam Syâthibî memberikan kreteria untuk seseorang bisa dikatakan sebagai mujtahid. Kreteria tersebut adalah, pertama dapat memahami maqâsyid alsyari'ah secara sempurna. Apa bila seseorang mampu memahami maqâsyid al-syari'ah dalam segala persoalan dengan rincianya, berarti ia telah mencapai pada level pemahaman khalifah-khalifah Nabi dalam mengajar, berfatwa dan menetapkan hukum sesuai dengan hukum yang diturunkan Allah Swt. Kedua kemampuan menarik kandungan hukum atas dasar pengetahuan dan pemahaman maqâsyid al-syarîa itu adalah dengan bantuan pengetahuan bahasa Arab, al-Qur'an dan Sunnah. Lihat Al-Syâthibî, Al-Muawafaqat Fi Ushul alSyariah, (Beirut: Dâr al-Kutub al-Ilmiyah, Juz II, 2003), 105-107

2Martin Van Bruinessen, Traditionalist Muslims in A Modernizing World: The Nahd\}atul Ulama and Indonesia's New Order Politics, Factional Conflict and The melalui gagasan KH. Abdul Wahhab Chasbullah setelah mendapatkan restu dari KH. Hasyîm 'Asy'âri.

Sebagai organisasi kumpulan para 'ulama, NU dalam memahami ajaran Islam sangat hati-hati. Permasalahanpermasalahan yang dihadapi baik urusan 'aqîdah, tasyawnuf maupun fikih, diselesaikanya tidak langsung merujuk kepada kedua sumber utama yakni alQur'an dan Sunnah. Hal ini dilaksanakan agar terhindar dari pemahaman yang keliru atas kedua sumber tersebut, mengingat banyak persyaratan yang harus dipenuhi bagi seseorang yang hendak memahami kedua sumber ajaran Islam tersebut secara langsung. Disamping alasan tersebut, juga didasari prinsip NU yang menyatakan bahwa perpindahan ilmu agama Islam tidak boleh terputus dari satu generasi ke generasi berikutnya. Maksudnya matarantai (sanad) ilmu agama Islam harus diketahui dengan baik dan benar. ${ }^{3}$

Menurut NU, matarantai (sanad) ${ }^{4}$ ilmu agama Islam, dapat diketahui dengan baik dan benar, manakala umat Islam menjalankan aktifitas keagamaanya dengan

Search for A New Discourse, Pent. Farid Wajidi (Yogyakarta: LkiS, Cet: IV, 2004), 13.

${ }^{3}$ Zamakhsyari Dlofier, Tradisi Pesantren, Studi Tentang Pandangan Hidup Kiyai (Jakarta: LP3ES, 1984), 149-153

${ }^{4}$ Matarantai dalam transfer ajaran tersebut dikenal dengan istilah sanad, sebuah istilah yang diadopsi dari istilah matarantai dalam periwayatan Hadits yang dikaji dalm ilmu dirâyah al-hadîth. Lihat Muhammad 'Ajaj al-Khatib, Ushûl al-Hadîth Ulûmuh wa Musythalabuh, (Beirut: Dar al-Fikr, 2006), 200. Menurut istilah hadits sanad adalah silsilah matarantai orang-orang yang menghubungkan kepada matan Hadits. Lihat Muhamad Ma'syum Zainy al-Hasyimiy, Pengantar Memahami Nadham Baiquiniyyah Jombang: Darul Hikmah Jombang, 2008), 14. Sedangkan yang dimaksud matarantai atau sanad di sini adalah silsilah orang-orang yang menghubungkan kepada mu'allif (pengarang kitab). 
cara ikut (taqlìd) atau bermazhab ${ }^{5}$ kepada salah satu pendapat empat mujtahid mazhab, yang keberadaanya telah tersohor dan aliran mazhabnya sudah dikodifikasikan. Selain itu, bermazhab bagi NU adalah hukumnya wajib, hal ini dilakukan karena dikhawatirkan umat Islam mencampur-kan antara yang $\underline{h} a q$ dan yang bâthil, atau tergelincir dalam kesalahan, atau mengambil serta mengamalkan ajaran Islam yang mudah-mudah saja. ${ }^{6}$ Oleh karena itu, dalam pandangan NU, tansmisi keilmuan atau matarantai keilmuan dianggap sebagai sebuah aspek integral dari konsep wasilah, keperantaan spiritual. Matarantai yang terus bersambung dari seorang guru, hidup atau mati, melalui guru-guru terdahulu dan sampai kepada Nabi Saw. dan karenaya kepada Tuhan, dianggap penting untuk keselamatan. Bahkan konsep sanad atau matarantai keilmuan agama sebagai aspek penting bagi kalangan Islam tardisional $(\mathrm{NU})^{7}$

Menurut Hasyim Asy'ari dengan cara mengikuti pendapat salah satu imam mazhab yang empat, maka umat Islam akan mendapatkan kemaslahatan dan kebaikan yang lebih besar, sebab hukum Islam tidak akan dapat dipahami kecuali dengan proses

${ }^{5}$ Kata mazhab (مذهب) menurut ilmu syaraf merupakan syighat isim makan (isim yang menunjukan kata tempat) yang diambil dari kata dasar dhababa (ذَهَبَ) yang berarti tempat berjalan. Maksudnya suatu tempat berpijak para imam mazhab dalam rangka mencurahkan pikiranya untuk menetapkan hukum Allah atas suatu persoalan, yakni meliputi empat macam dalil, yaitu Al-Qur'an, Hadits, Ijma' dan Qiyas. Lihat Misbah Mustofa, Anda Ablussunnab? Anda Bermadzhab? (Tuban: al-Misbah, 2006), cet. Ke I, 12

${ }^{6}$ Tentang fatwa diwajibkanya mengikuti salah satu dari empat mazhab diputuskan pada Muktamar ke-1 di Surabaya pada tanggal 13 Rabî’ al-Thânî 1345 H./21 Oktober 1926 M. Dan pada Muktamar ke-14 di Magelang pada tanggal 14 Jumâdî al-'Ulâ 1358 H./1 Juli 1939 M. Fatwa ini merujuk ke beberapa kitab istinbatth al-abkâm (penggalian hukum) melalui sumber-sumbernya dengan benar. Sedangkan untuk memperoleh kebenaran dalam proses istinbâth al-abkâm harus mengenali pendapat-pendapat sebelumnya supaya tidak keluar dari ijma'. Dalam pengantar Undang-Undang Dasar NU disebutkan bahwa barang siapa menyebutkan ilmu dengan tidak menyebutkan sanadnya maka dia seperti pencuri. ${ }^{8}$ Hal itu menunjukkan bahwa mengikuti pendapat-pendapat imam mazhab sangat penting untuk memutuskan suatu perkara, terutama untuk mengembangkan pemikiran yang berkaitan dengan ijtihad.

\section{Pembahasan}

\section{Hakikat Ijtihad Menurut NU}

Pada dasarnya term. ijtihad tidak begitu popular di kalangan NU, karena menurut NU kegiatan ijtihad merupakan hak otoritas seorang mujtahid yang telah mempunyai beberapa persyaratan yang telah ditetapkan oleh ulama ahli ushul. Banyak persyaratan yang harus dipenuhi bagi seseorang yang berhak dan layak menjadi mujtahid, seperti mampu menguasai Al-Qur'an dan ilmu-ilmu yang terkait dengannya, mampu menguasai

karangan ulama-ulama salaf, diantara kitab-kitab tersebut adalah: Al-Mizân Al-Kubrâ karangan Abdul Wahhab Al-Sya'rani; Al-Fatawa Al-Kubrâ Al-Fiqhiyyah karangan Ibn Hajar Al-Haitamî; Sullam Al-Wusûl Syarab Nihâyah Al-Sûl karangan Muhammad Bahîth Al-Mu'thî; Bughyah Al-Mustarsyidin karangan 'Abd AlRahmân Ba'alawî. Lihat Nahd\} atul Ulama, Abkâm alFuqâhâ; Solusi Problematika Aktual Hukum Islam, Keputusan Muktamar, Munas dan Konbes Nabd\}atul Ulama 1926-2010. (Surabaya: Khalista dan Lajnah Ta'lif Wa Al-Nasyr, 2011), 2-3 dan 248-250.

${ }^{7}$ Muhammad Iqbal, Hukum Islam Indonesia Modern: Dinamika Pemikiran dari Fikih Klasik ke Fikih Indonesia (Tangerang: Gaya Media Pratama, 2009), cet. I, 61

'Hasyîm Asy'ari, Ibyâ' 'Amal al-Fud\}âla; Muqaddimah Anggaran Dasar NU (Kendal: tp., 1969), 37-38 
Hadits beserta ilmu-ilmu yang berhubungan dengannya, menguasai bahasa Arab beserta ilmu-ilmu yang berkaitan dengannya, menguasai ilmu usyul fiqh, menguasai maqâsyid al-syarìah dan lain sebagainya.

Oleh karena itu, NU melalui Lajnah Bahtsul Masail dalam menyelesaikan suatu masalah, tidak pernah menggunakan istilah ijtihad untuk kegiatan tersebut yang mana ijtihad sudah diyakini sebagai hak otoriter mujtahid terdahulu, melainkan memakai term Istinbâth (penggalian dan penetapan) hukum dengan pendekatan mazhabî. Maksudnya para ulama yang tergabung dalam bahtsul masail, ketika menyelesaikan suatu masalah berorientasi kepada salah satu mazhab empat, baik pendapat-pendapatnya tentang suatu masalah yang disebut dengan bermazhab secara qawli maupun jalan pikiran yang digunakan oleh imam mazhab dalam menyelesaikan suatu masalah yang disebut dengan bermazhab secara manhaji.

Dalam tradisi NU, ijtihad seakan-akan telah tertutup dan tidak mungkin dilakukan oleh ulama-ulama sekarang karena tidak mempunyai kompetensi sebagaimana para mujahid terdahulu. ${ }^{10}$ Melalui kerangka bermazhab inilah, maka pintu ijtihad menurut NU hanya terbuka dalam kerangka pemikiran bermazhab. ${ }^{11}$

Sebenarnya istilah Istinbâth merupakan istilah lain dari ijtihad yang hendak dihindari oleh ulama-ulama NU. Secara esensial kedua istilah tersebut adalah sama. Kedua istilah tersebut lebih dikonotasikan kepada istikhrâj al-hukm min al-nushûsh (mengeluarkan hukum

\footnotetext{
${ }^{9}$ Ahamad Zahro, Tradisi Intelektual NU; Lajnah Babtsul Masail 1926-1999 (Yogyakarta: LKiS, 2004), cet. Ke I, 17

${ }^{10}$ Husein Muhammad, "Tradisi Isinbat Hukum NU: Sebuah Kritik", dalam M. Imdadun Rahmat (ed), Kritik Nalar Fiqih NU: Transformasi Paradigma Babtsul Masail (Jakarta: LAKPESDAM NU, 2002), 27-28. Bandingkan dengan Syaista P. Ali-Karamali and Fiona
}

dari teks-teks primer; al-Qur'an dan Sunnah) yang mana kegiatan tersebut hanya bisa dilakukan oleh seorang mujtahid mutlak, yang menurut NU kegiatan tersebut sangat berat untuk dilakukan ulama sekarang dengan segala keterbatasannya baik dalam ilmu pokok yaitu penguasaan ilmu tentang al-Qur'an dan Sunnah maupun ilmu bantu yaitu penguasaan dalam bidang ilmu bahasa Arab dan lain sebagainya.

Menurut K.H. Sahal Mahfud, istinbâth hukum langsung dari sumber primer yang cenderung kepada pengertian ijtihad mutlak, bagi ulama NU, masih sangat sulit dilakukan karena keterbatasan-keterbatasan yang memang disadari terutama dalam ilmu-ilmu pokok dan ilmu penunjang yang harus dikuasai oleh seorang mujtahid. Sementara jika ijtihad dilakukan dalam batas mazhab yang lebih praktis, maka dapat dilakukan oleh semua ulama NU yang telah mampu memahami 'ibârat kitab-kitab fikih sesuai dengan terminologinya yang baku. ${ }^{12}$

Istinbâth hukum di kalangan NU diartikan bukan untuk mengambil hukum secara langsung dari kedua sumber hukum yang asli yakni Al-Qur'an dan Sunnah, melainkan -sesuai dengan sikap dasar bermazhab- melakukan tathbîq (penerapan) secara dinamis terhadap nasy-nasy (teks-teks) yang telah dielaborasi ulama fikih priode klasik dan menengah kepada persoalan waqi'iyyah (kasuistik) yang dicari hukumnya. Sedangkan istinbâth dalam pengertian yang pertama (menggali hukum secara langsung dari Al-Qur'an dan Sunnah) cenderung kea

DunneSource, "The Ijtihad Controversy", dalam Journal Arab Law Quarterly, Vol. 9, No. 3 (1994), pp. 238-257 Publisyed by: BRILL Stable URL: http://www.jstor.org/stable/3381568. Diakses pada tanggal 25 Mei 2014

${ }^{11}$ Ahmad Zahro, Tradisi Intelektual NU;...117

${ }^{12}$ Muhammad Sahal Mahfudh, Nuansa Fikih Sosial (Yogyakarta: LKiS, 1994), 27 
rah perilaku ijtihad yang oleh para ulama NU dirasa sangat sulit karena keterbatasanketerbatasan yang disadari oleh mereka. Terutama dibidang ilmu-ilmu penunjang dan pelengkap yang harus dikuasai oleh seorang mujtahid. Sedangkan istinbâth menurut pengertian yang kedua, selain praktis, dapat dilakukan oleh semua ulama NU yang telah mampu memahami 'ibârat-ibârat kitab fikih sesuai denga terminologinya yang baku. Oleh karena itu, di kalangan NU istilah istinbâth dalam kerja bahth al-masailnya Syuriyyah tidak popular karena istilah tersebut sudah popular dikalangang NU dengan konotasinya yang pertama yaitu ijtihad. Sebagai gantinya dipakai istilah bahtsul masail yang artinya membahas masalah-masalah waqi'iyyah (yang terjadi) melalui refernsi (marâji') yaitu al-kutub al-mu'tabarah. ${ }^{13}$

Secara definitif, NU memberikan definisi Istinbatth hukum sebagai suatu upaya mengeluarkan hukum syara' dengan qawâid usyûliyyah dan qawaid fiqbiyyah, ${ }^{14}$ baik berupa adillah ijmâliyyah, adillah tafsyiliyyah maupun adillah al-abkâm. Dengan demikian produk hukum yang dihasilkan merupakan hasil ijtihad ulama atas nasy-nasy al-Qur'an dan Sunnah yang sesuai dengan prinsip-prinsip ijtihad yang digunakan para mujtahid masa lalu.

\footnotetext{
${ }^{13}$ Sahal Mahfudh, "Bahtsul Masail dan Istinbath Hukum NU: Sebuah catatan pendek" dalam A. Ma'ruf Asrori dan Ahmad Muntaha (eds), Abkâm alFuqâhâ: Solusi Problematika Aktual Hukum Islam Keputusan Muktamar, Munas dan Konbes 1926-2010 (Surabaya: Khalista dan Lajnah Ta'lif Wan Nasyr (LTN) PBNU, 2011), viii-ix

${ }^{14}$ Nahdlatul Ulama, Abkêm al-Fuqâhâ,...470

${ }^{15} \mathrm{NU}$ dikategorikan sebagai Islam Tradisionalis karena pola pikirnya yang cenderung menaruh penghormatan dan penghargaan yang berlebihan terhadap karya-karya ulama terdahulu, sehingga berimbas kepada cara mereka menyelesaikan suatu masalah yaitu mereka perlu berkonsultasi dengan kitab-kitab yang dianggap mu'tabarah (diakui) yang
}

\section{Hubungan Ijtihad NU dengan Fikih Empat Mazhab}

Sebagaimana dijelaskan di atas bahwa, NU dalam menjalankan segala aktifitasnya, baik yang praktis maupun teoritisnya, menggunakan sistem bermazhab. Hal ini dilakukan karena untuk mencapai kebenaran dalam menjalankan ajaran Islam agar sesuai dengan tuntunan syarî̀at, maka seorang muslim harus mengikuti apa yang sudah pernah dilakukan oleh ulama-ulama terdahulu, karena untuk zaman sekarang ini, sulit ditemukan orang-orang yang mempunyai kemampuan setingkat mujtahid yang mampu langsung memahami ayat-ayat al-Qur'an dan Hadits.

Zamakhsyari Dlofier menyebutkan bahwa, pemikiran Islam Tradisiona ${ }^{15}$ adalah pemikiran-pemikiran yang masih terikat kuat dengan pemikiran-pemikiran ulama ahli fiqh, Hadits, tasawwuf, tafsir dan tauhid yang hidup antara abad ke-7 M hingga abad ke-13 M. ${ }^{16}$ Dalam konteks fikih, pengambilan dasar hukum Islam tidak langsung merujuk kepada sumber aslinya yakni Al-Qur'an dan Sunnah Nabi, melainkan dilakukan oleh ulama-ulama tradisonalis (NU) dengan berpegang teguh terhadap apa yang telah dibangun oleh para imam Hanafi $^{17}$, Maliki ${ }^{18}$, Syafi' ${ }^{19}$ dan

ditulis ulama mazhab empat. Lihat Ahmad Zahro, Tradisi Intelektual NU,...116

16Zamakhsyari Dhofier, Tradisi Pesantren Studi tentang Pandangan Hidup Kyai (Jakarta: LP3ES, 1994), cet. Ke-6, 1

${ }^{17}$ Nama aslinya adalah al-Nu'mân ibn Thâbit ibn Zauti, lahir di Kufah tahun $80 \mathrm{H}$.

${ }^{18} \mathrm{Nama}$ aslinya adalah Malik ibn Anas ibn Abi 'Amir, lahir di Madinah tahun $93 \mathrm{H}$.

${ }^{19} \mathrm{Nama}$ aslinya adalah $\mathrm{Abu}$ 'Abdillah Muhammad ibn Idris ibn al-'Abbas ibn 'Uthman ibn Syafi' al-Syâfi'i al-Muthallibi (keturunan dari alMuthallib ibn Abdi Manaf, lahir di Ghuzah pada tahun $150 \mathrm{H}$. 
Hanbali). ${ }^{20} \mathrm{Hal}$ ini terjadi, karena NU merupakan komunitas para ulama yang sangat menghargai dan menghormati karya ulama-ulama terdahulu, namun kurang mempertanyakan relevansi pemikiranpemikiran tersebut dengan kondisi sekarang ini.

Ahmad Arifi mengemukakan tiga alasan mengapa penganut mazhab (termasuk NU) memegangi pemikiran mazhab mereka. Ketiga alasan tersebut adalah sebagai berikut:

a. Pemikiran mazhab telah terbukukan secara sistematis sehingga mudah mempelajarinya.

b. Kredibilitas imam mazhab dan kehebatan pemikiranya telah teruji oleh sejarah. Hal ini terbukti dengan diikutinya para imam mazhab oleh sebagian besar umat Islam di seluruh penjuru dunia.

c. Mengikuti pemikiran imam mazhab memiliki nilai praktis dan pragmatis. Dengan mengikuti pemikiran mazhab tidak perlu bersusah-susah untuk memulai dari awal dalam mencari solusi dan menjawab permasalahan hukum yang dihadapi, apalagi ketika masalah tersebut

${ }^{20}$ Nama aslinya adalah Ahmad ibn Hanbal ibn Hilâl al-Zihli al-Syaybani al-Maruzi al-Baghdadi, lahir tahun $163 \mathrm{H}$. dan wafat tahun $241 \mathrm{H}$.

${ }^{21}$ Ahmad Arifi, "Pergulatan Fiqh dalam fikih Nahdlatul Ulama: Analisis Paradigma atas fikih Tradisi”. Disertasi, (Yogyakarta: PPs UIN Yogyakarta, 2007), 156

22Abdurrahman Wahid, Prisma Pemikiran Gus Dur (Yogyakarta: LKiS, 2000), 153.

${ }^{23}$ Nama lengkapnya Abu al-Hasan Ibn Isma'il al-Asy'ari lahir di Basrah 873 M, wafat di Baghdad 935 M. Pada mulanya ia adalah murid al-Juba'i dan salah seorang tokoh terkemuka dalam golongan Mu'tazilah sehingga, menurut al-Husain Ibn Muhammad alAsykari, al-Juba'i berani mempercayakan perdebatan dengan lawan kepadanya. Lihat Harun Nasution, Teologi Islam: Aliran-Aliran, Sejarah Analisa dan Perbandingan (Jakarta: Penerbit Universitas Indonesia, 1986), 65. menghendakisegera untuk diperoleh jawabanya. ${ }^{21}$

Sistem bermazhab bagi komunitas NU merupakan sebuah keniscayaan sebagai tradisi keilmuan yang selalu dipegangi baik dalam tataran individu maupun dalam tataran organisasi NU. Tradisi keilmuan yang dianut komunitas NU dengan mengikuti pola bermazhab seperti ini sesungguhnya telah dikemukakan secara terbuka oleh warga NU sendiri sejak permulaan berdirinya, dalam AD/ART NU dijelaskan bahwa asas organisasi NU adalah berakidah Islam abl alsunnah wa al-jamâ'ah. ${ }^{22}$

Secara operasional akidah Islam abl alsunnah wa al-jamâ'ah dijelaskan dengan berpangkal pada tiga panutan yaitu dalam bertauhid mengikuti paham Abu Hasan alAsy'ari $^{23}$ dan Abu Mansur al-Maturidi ${ }^{24}$, dalam berfikih mengikuti salah satu madhab fikih empat yang terkenal dengan sebutan almadhābib al-arba'ah (Hanafi, Maliki, Syâfi'i, dan Hanbali), dan dalam bertasawuf mengikuti cara yang ditetapkan dan dirumuskan al-Junaid al-Baghdadi ${ }^{25}$ dan Abu Hamid Muhammad bin Muhammad alGhazali. ${ }^{26}$ Pada dasarnya Inti dari tradisi keilmuan yang dianut NU adalah perpautan

${ }^{24}$ Nama lengkapnya adalah Abu Mansur Muhammad Ibn Muhammad Ibn Mahmud alMaturidi, lahir di Samarkand pada pertengahan ke-2 dari abad ke-9 M. dan meninggal pada tahun $944 \mathrm{M}$. Ia adalah pengikut Abu Hanifah dan paham teologinya banyak persamaannya dengan paham yang dimajukan oleh Abu Hanifah. Sistem pemikiran teologi yang ditimbulkan Abu Mansur termasuk dalam golongan teologi abl al-sunnah dan dikenal dengan nama al-Matüridiah. Lihat Harun Nasution, Teologi Islam,... 72.

${ }^{25} \mathrm{Nama}$ aslinya adalah Junaid ibn Muhammad Abu al-Qâsim al-Khazzaz al-Baghdadi

${ }^{26}$ Lihat AD/ART NU Pasal 6. Nama aslinya adalah Abu Hamid al-Ghazāli Muhammad ibn Muhammad al-Ghazāli al-THūsi, dia berkebangsaan Persia asli, lahir pada tahun $450 \mathrm{H} . / 1058 \mathrm{M}$. di T \{usi (dekat Mesyed) sebuah kota kecil di Khurisan (sekarang Iran), di sini pula A1-Ghazâli wafat di 
organis antara tauhid, fikih, dan tasawuf secara integral, yang dalam jangka panjang dapat menumbuhkan pandangan terpautnya sendiri antara dimensi duniawî dan ukhrawi dari kehidupan. Perpautan antara dimensi duniaw $\hat{\imath}$ yang profane dan dimensi ukhraw yang sakral dari kehidupan ini merupakan mekanisme kejiwaan yang lazim dan berkembang di kalangan warga NU untuk menghadapi tantangan sekularisme terangterangan yang timbul dari proses modernisasi dan westernisasi. ${ }^{27}$

Penjelasan tentang akidah Islam ablalsunnah wa al-jamâ'ab diperjelas lagi oleh alHäsyiah al-Syanwani sebagaimana dikutib Syaykh Hasyim Asy'ari dalam Risâlab Ablussunnah wal jamaah. ${ }^{28}$ Dan dipertegas ulang oleh Pengurus Wilayah Nahdlatul Ulama (PWNU) Jawa Timur dalam sebuah buku saku yang berjudul Aswaja $A n$ Nabdliyyah: Ajaran Ablussunnah wal jama'ah yang berlaku di lingkungan Nahdlatul Ulama. ${ }^{29}$

Dalam konteks berfikih, NU pada dasarnya tidak hanya mengakui empat mazhab saja yang boleh diikuti oleh umat Islam. Mazhab-mazhab lainnya pun boleh diikuti, seperti Sufyan al-Thauri, Sufyan bin 'Uyainah, Isyaq bin Rahawaih serta Daud alDHâhiri. Hanya saja, karena mereka tidak memiliki pengikut yang setia yang mengembangkan mazhab mereka dan tidak banyak literature yang memuat pemikiranpemikiran mereka secara khusus, sehingga

Nazran tahun 505H./1111 M. Tentang biografinya, dapat dilihat antara lain: Sulaiman Dunya, al-Haqîqah Fî Naẓbr al-Ghazâli, cet. III (Mesir Dar al-Ma'arif, 1971).

${ }^{27}$ Abdurrahman Wahid, Prisma Pemikiran Gus Dur...155

${ }^{28} \mathrm{KH}$. M. Hasyim Asy'ari, Risalah Abl Assunnah wa al-Jamä'ab: fi Hadith, al-Mauta wa Asyrät, as-Sä'ab wa Bayān Mafhū as-Sunnah wa al-Bid'ah (Jombang: Maktabah at-Turas al-Islami bi Ma'had Terbuireng, $1418 \mathrm{H}), 23$. matarantai pemikiran serta keilmuan mereka menjadi terputus. ${ }^{30}$

Keempat mazhab fikih yakni Hanafi, Maliki, Syafi'i dan Hanbali merupakan mazhab fikih yang menjadi pegangan bagi umat Islam aliran Ablal-Sunnah wa al-Jama'ah. Hal ini pernah ditegaskan oleh Khalifah Malik al-DHâhir yang hanya memberlakukan empat mazhab yang boleh dijadikan pegangan umat Islam. Begitu juga Khalifah al-Qadir juga memberlakukan keempat mazhab fikih sebagai mazhab resmi juga diikuti dengan pembakuan aliran $A b l$ alSunnah wa al-Jamâ'ab sebagai paham resmi Negara. ${ }^{31}$

Ketentuan NU yang mengharuskan mengikuti salah satu diantara keempat mazhab fikih tersebut, sebagaimana yang tertuang dalam AD/ART NU pasal 6, ternyata belum sepenuhnya mencerminkan keseimbangan dalam setiap pengambilan keputusan hukum bahtsul masail NU. Dalam praktiknya NU mempunyai kecenderungan mengikuti mazhab Syafi'i secara lebih dominan dibandingkan dengan ketiga mazhab yang lain. Hal ini tampak dalam setiap keputusan bahtsul masail. Teks-teks dasar yang dijadikan rujukan dalam pengambilan keputusan kebanyakan fatwa NU masih didominasi pendapat dari mazhab Syafi'i, seperti kitab Minhâj al-THalibin karya al-Nawawi, al-Mubarrar karya al-Dimasyqi, Fath al-Mu'în karya Syamsuddin al-Malibari, I'ânah al-THâlibîn karya Sayyid Bakri al-

${ }^{29}$ Masyhudi Muchtar dkk, Aswaja An-Nabdliyyah: Ajaran Ablussunnab wal jama'ab yang berlaku di lingkungan Nabdlatul Ulama (Surabaya: Khalista dan Lajnah Ta'lif Wa al-Nasyr (LTN) NU Jawa Timur) cet. Ke-II, 2007, 11-30

${ }^{30}$ Saifullah Ma'syum, Karisma Ulama, Kebidupan Ringkeas 26 Tokob NU (Bandung: Mizan, 1998), 80

${ }^{31}$ George Makdisi, "The Sunni Revival", dalam Islamic Ciilization 950-1150 (Papers on Islamic History III), ed. D.H. Ricards (Oxford: Cassier-The Near East Center Unviersity of Pannsylvania, 1973), 164 
Dimyatî, Kanzal-Râghibîn karya Jalaluddin alMahallî, Syarh Kanz al-Raghibin karya alQulyubî, Tuhfah al-Mubtâj karya Ibn Hajar alHaitamî, Mughny al-Mubtâj karya Syarbinî dan Nihâyah al- Mubtâj karya al-Ramli. ${ }^{32}$

Bahkan, kecenderungan mengikuti mazhab Syafi'i secara lebih dominan dibanding dengan tiga mazhab lain, sesungguhnya sering "tidak konsisten" karena tidak hanya terbatas mengikuti pada pandangan imam mazhab, tetapi juga pendapat ulama-ulama turunannya yang telah mengembangkan tidak hanya literatur keputusan hukum agama dalam skala massif, melainkan juga cara-cara untuk menyusun pemikiran hukum, menentukan bentuk akhir keputusan hukum yang akan diambil jika kondisinya dan persyaratan yang melatarbelakangi sesuatu masalah yang tadinya sudah diputuskan ternyata telah mengalami perubahan. Di sinilah letak dinamika perkembangan hukum Islam melalui fikih dapat dilakukan, walaupun dalam batasan-batasan yang tetap masih ketat karena harus tidak boleh keluar dari lingkup bermazhab. ${ }^{33}$

Kecenderungan mengikuti mazhab Syafi'i tersebut dikarenakan keterbatasan referensi di luar mazhab Syafi'i dan kebiasaan para pengkajinya yang mayoritas di lingkungan pesantren yang diasuh oleh para kyai yang mengajarkan kitab-kitab syafi'iyyah seperti Fath al-Qarîb al-Mujîh, Fath al-Mu'în, Fath al-Wabhâb dan lain sebagainya.

Terhadap kemungkinan pengambilan keputusan dengan menggunakan pendapat ulama yang paling dominan, Sistem Pengambilan Keputusan Bahtsul Masail NU (SPKBMNU) mengikuti cara baku yang

${ }^{32}$ M.B. Hooker,Islam Mazhab Indonesia: Fatwafatwa dan perubahan Sosial, terj. Iding Rassyidin Hasan (Jakara: Teraju, 2002), 88 telah disepakati di kalangan ulama NU yang telah memberikan alternative pilihan yang disusun secara hirarkhis. Pertama, kesepakatan pendapat Nawâwî dan Râfi'î; kedua, pendapat Nawâwî; ketiga, pendapat Râfi'î; keempat, pendapat yang didukung mayoritas ulama; kelima, pendapat ulama terpandai dan keenam, pendapat ulama paling wara'. ${ }^{34}$ Diantara pendapat para ulama yang sering digunakan selain pendapat Nawâwî dan Râfî̀i adalah al-Muzanî, al-Ramlî, ibn Hajar al-Haitamî, Zakaria al-Ansyârî dan sebagainya. Pendapat ulama-ulama tersebut lebih banyak digunakan dari pada pendapat Imam Syafi'i sendiri. Dengan kata lain, sebenarnya NU dalam sistem bermazhab lebih mengikuti pendapat "syafi'iyyah" dari pada "Syafi'i".

Jika dilihat dari frekuensi penggunaan kitab-kitab dalam bahtsul masail, maka akan tampak jelas bahwa NU lebih cenderung kepada mazhab Syafi'i dibandingkan dengan ketiga mazhab yang lain. Kitab-kitab yang dimaksud adalah kitab-kitab yang dianggap mu'tabarab oleh kalangan NU, yaitu kitabkitab dari madhâbib al-arba'ab (Hanafi, Maliki, Syafi'i dan Hanbali) dan kitab-kitab lain yang memenuhi kriteria fikerah nabdliyyah. ${ }^{35}$

Menurut Ahmad Zahro, kitab-kitab yang dianggap masyhur dalam mazhab Hanafi ada 28 jenis kitab. Namun yang digunakan untuk menyelesaikan permasalahan dalam bahtsul masail hanya 4 kitab. Sedangkan kitab-kitab yang dianggap masyhur dalam mazhab Maliki ada 19 jenis kitab, tetapi yang digunakan dalam bahtsul masail hanya 2 kitab. Kemudian kitab-kitab yang di anggap masyhur dalam mazhab Syafi'i ada 26 jenis kitab, dari 26 jenis kitab

${ }^{33}$ Abdurrahman Wahid, Prisma Pemikiran Gus Dur...154

${ }^{34} \mathrm{Nahdlaul}$ Ulama, Abkâm al-Fuqâhâ.....472

${ }^{35}$ Nahdlatul Ulama, Ahkâm al-Fuqâhâ....862 
yang digunakan dalam bahtsul masail ada 15 kitab. Sedangkan dari mazhab Hanbali kitabkitab yang dianggap masyhur ada 16 jenis kitab, dari sederetan jenis kitab tersebut yang digunakan dalam bahtsul masail hanya ada 2 jenis kitab. ${ }^{36}$

Dari uraian tersebut dapat disimpulkan bahwa kitab-kitab Syafi'iyyah adalah kitab yang paling banyak digunakan dalam bahtsul masail dibanding dengan kitab mazhab yang lain. Hal ini asumsikan ada dua faktor. Pertama, Lajnah Bahtsul Masail merasa tidak perlu mengikutsertakan pendapat-pendapat dari mazhab lain dalam keputusan-keputusannya karena tidak berguna bagi kehidupan praktis sehari-hari, mengingat mayoritas warga NU bermazhab Syafi'i. Kedua, kebanyakan anggota Lajnah Bahtsul Masail tidak mempunyai kitab-kitab tersebut. Sedangkan dominannya penggunaan kitab-kitab syafi'iyyah bukanlah suatu hal yang mengherankan, mengingat mayoritas anggota Lajnah Bahtsul Masail adalah para ulama yang latar belakang pendidikannya berasal dari pesantren yang hampir seratus persen kitab fikih yang diajarkan di dalam pesantren adalah kitabkitab yang bermazhab Syafi'i. Konsekuensi logisnya adalah bahwa, kitab-kitab yang mereka miliki maupun perhatian dan pemikiran fikih mereka tentu berada dalam kawasan fikih Syafi'i. ${ }^{37}$

\section{Lembaga Ijtihad (Lajnah Bahtsul Masail) NU dan Kitab Kuning}

a. Lajnah Bahtsul Masail (LBM) dalam Lintasan Sejarah

${ }^{36} \mathrm{Ahmad}$ Zahro, Tradisi Intelektual NU....84-95

${ }^{37} \mathrm{Ahmad}$ Zahro, Tradisi Intelektual NU....93

${ }^{38}$ Sebagai organisasi sosial-keagamaan, NU mempunyai tujuan untuk mengembangkan kegiatankegiatan keagamaan, pendidikan, ekonomi dan sosial.
NU sebagai organisasi sosial-keagamaan (jam'iyyah diniyyah-ijtimâ'iyyah), ${ }^{38}$ yang berada dibawah kepemimpinan para ulama dan kyai, sebagian besar jam'iyyabnya tersebar luas di daerah pedesaan Jawa - Madura. Basis massa yang demikian ini sering memposisikan NU menjadi kelompok marginal yang kurang diperhitungkan dalam wacana pemikiran Islam di Indonesia. Sebagai organisasi yang berada di bawah naungan para kyai dan ulama, NU berusaha mempertahankan tradisi keagamaan yang sedang berlangsung dianut oleh masyarakat dengan mengakomodir seluruh tradisi masyarakat tanpa mengurangi akselerasi nilai-nilai universal Islam. ${ }^{39}$

NU sebagai organisasi sosial keagamaan mempunyai rasa tanggungjawab moral terhadap persoalan yang terjadi di masyarakat. Atas dasar inilah, kemudian NU membentuk lembaga yang membahas segala persoalaan mulai dari politik, ekonomi, sosial, budaya. Forum itu disebut Lajnah Bahtsul Masail (LBM), yang dikoordinatori oleh lembaga Syuriyah (legislatif). LBM merupakan lembaga atau Forum yang bertugas mengambil keputusan tetang hukum-hukum Islam baik yang berkaitan dengan masâ'il fiqbiyah (masalah fikih) maupun masalah ketauhidan dan bahkan masalah-masalah tasawwuf (tarekat). Seperti yang tertuang dalam Anggaran Dasar dan Anggaran Rumah Tangga NU, dalam butir F pasal 16 menyatakan bahwa, tugas bahtsul masail adalah menghimpun, membahas dan memecahkan masalah-masalah yang mawqûf

${ }^{39}$ Winarno "Pergesaran Ijtihad dalam Bahtsul Masail Nahdlatul Ulama". Resensi buku "Dinamika Ijtihad NU" penulis Imam Yahya, penerbit: Semarang: Walisongo Press, 2009. Dalam jurnal SUHUF, Vol. 21, No. 2, Nopember 2009, 
dan waqî'iyah yang harus segera mendapatkan kepastian hukum. ${ }^{40}$

Forum ini biasanya diikuti oleh Syuriyah dan ulama-ulama NU yang berada di luar struktur organisasi termasuk para pengasuh pesantren. Masalah-masalah yang dibahas umumnya merupakan kejadian (waqi'iyyah) yang dialami oleh anggota masyarakat yang diajukan kepada Syuriyah oleh organisasi ataupun perorangan. Masalah-masalah itu setelah di inventarisasi oleh Syuriyah lalu diadakan skala prioritas pembahasannya. Dan apabila dalam pembahasan itu terjadi kemacetan (mawquf) maka akan diulang pembahasannya dan kemudian dilakukan ke tingkat organisasi yang lebih tinggi: dari Ranting ke Cabang, dari Cabang ke Wilayah, dari Wilayah ke Pengurus Besar dan dari PB ke Munas dan pada akhirnya ke Muktamar. ${ }^{41}$

Forum bahtsul masail di kalangan NU diyakini merupakan tradisi intelektual yang berkembang sejak lama, bahkan forum bahtsul masail ini sudah ada sebelum NU berdiri. Sebetulnya forum bahtsul masail telah berkembang di tengah masyarakat muslim tradisional pesantren jauh sebelum tahun 1926 dimana NU didirikan. Saat itu sudah ada tradisi diskusi di kalangan pesantren yang melibatkan kiai dan santri yang hasilnya diterbitkan dalam buletin LINO (Lailatul Ijtima Nahdlatul Oelama). Dalam buletin LINO, selain memuat hasil, bahtsul masa'il juga menjadi ajang diskusi interaktif jarak jauh antar para ulama. Seorang kiai menulis ditanggapi kiai lain, begitu seterusnya. ${ }^{42}$

\footnotetext{
${ }^{40}$ Imam Yahya, Dinamika Ijtibad NU, (Semarang: Walisongo Press, 2009), cet. Ke-I, 39

${ }^{41}$ Sahal Mahfudh " Bahtsul Masail dan Istinbath Hukum NU: Sebuah catatan pendek", ... vi

${ }^{42}$ Lihat Sahal Mahfudh "Bahtsul Masail dan Istinbath Hukum NU: Sebuah catatan pendek", ...vii. Bandingkan Imam Yahya, Dinamika Ijtihad NU...42
}

Menurut Martin van Bruinessen, forum tradisi bahtsul masail yang berkembang di kalangan NU bukanlah murni dari gagasan para kyai dan ulama NU. Melainkan tradisi yang diimpor dari Tanah Suci Makkah. Tradisi tersebut sudah ada di Tanah Suci Makkah yang disebut dengan tradisi $\underline{\text { balaqah. }} .^{43}$ Tradisi balaqah inilah yang diadopsi oleh para santri Indonesia yang belajar di Tanah Suci Makkah, ketika mereka pulang ke tanah air Indonesia, sistem balaqah diterapkan di lembaga pendidikan pesantren guna mengkaji persoalan-persoalan yang terjadi di masyarakat.

Pendapat Martin van Bruinessen tentang adopsi sistem halaqah yang dilakukan oleh para santri Indonesia bisa dipahami, mengingat bahwa pada akhir abad ke 19 ketergantungan umat Islam Indonesia terhadap fatwa yang dikeluarkan oleh ulama Timur Tengah, terutama ulama dari Kairo dan Makkah sangat besar. Hal ini dibuktikan dengan adanya sebuah buku yang berjudul Mubimmat al-Nafâis. Buku tersebut berisi fatwa-fatwa yang mengacu kepada beberapa isu yang berkembang di Nusantara (Indonesia) pada saat itu. Buku tersebut pertama kali diterbitkan pada tahun 1892 di Makkah. Kemudian pada tahun 1913 buku tersebut banyak dijual di toko-toko kitab Muslim di Indonesia. ${ }^{44}$

Usaha para santri lulusan Timur Tengah dalam rangka mengadopsi sistem balaqah adalah mendirikan forum Tasymîr alAfkâr pada tahun 1919 di Surabaya atas inisiatif KH. Abdul Wahab Chasbullah yang pernah menimba ilmu beberapa tahun di

${ }^{43}$ Martin Van Bruinessen, Kitab Kuning, Pesantren dan Tarekat: Tradisi-tradisi Islam di Indonesia (Bandung: Mizan, 1996), 34

${ }^{44}$ Nadirsyah Hosen, "Nahdlatul Ulama and Collective Ijtihad" dalam journal New Zealand Journal of Asian Studies 6,1 (Juni 2004), 5 
Tanah Suci Makkah. Awal mulanya forum ini ditujukan untuk membahas tema-tema keagamaan, walaupun pernah juga membahas beberapa peristiwa sosial politik yang sedang berkembang saat itu. ${ }^{45}$ Atas dasar itulah, dapat dikatakan bahwa forum Taswir al-Afkâr merupakan embrio tumbuhnya bahtsul masail di dalam organisasi NU.

Pada awalnya bahthul masail yang ada di NU tidak dilembagakan layaknya sebuah organisasi yang mempunyai struktur organisaai dan agenda resmi. Namun untuk menjadikan bahthul masail menjadi wadah yang lebih dinamis, maka pada Muktamar ke 28 di Yogyakarta tahun 1989, komisi I yang membidangi bahthul masail merekomendasikan kepada PBNU untuk mendirikan "Lajnah Babthul Masâil Diniyyah" (lembaga pengkajian masalah-masalah agama) sebagai lembaga permanen yang khusus menangani persoalan keagamaan. Hal ini didukung oleh balaqah yang diadakan di Pesantren Mamba'ul Ma'arif Denanyar Jombang pada tanggal 26-28 Januari 1990 yang merekomendasikan dibentuknya "Lajnah Bablthul Masâil Diniyab" sebagai wadah berkumpulnya ulama dan intelekual NU untuk melakukan ijtihad jamầî (ijihad kolektif). Berkat desakan Muktamar XXVIII dan halaqah Denanyar tersebut, maka pada tahun 1990 dibentuklah Lajnah Bahtsul Masâil secara legal formal berdasarkan surat keputusan PBNU Nomor 30/A.I.05/5/1990. ${ }^{46}$

LBM bukanlah satu-satunya forum yang mempunyai wewenang dalam menjawab segala permasalahan keagamaan yang dihadapi oleh umat muslim yang ada di

${ }^{45}$ Abdul Mun'in DZ, "Bahtsul Masail Tradisi Akademik Muslim Tradisionalis", dalam Jurnal Gerbang, vol. 12, tahun 2002, 108
Indonesia. Kalau NU mempunyai forum kajian keilmuan-keagamaan yang disebut Lajnah Bahtsul Masail (LBM), maka organisasi Islam lainnya pun juga mempunyai forum untuk menyelesaikan masalah keagamaan, walaupun dalam hal-hal tertentu ada perbedaan dengan LBM. Di SI (Sarikat Islam) forum tersebut dinamakan Majlis Syuro, di Muhammadiyah forum tersebut dinamakan Majlis Tarjih (MT), di PERSIS (Persatuan Islam) forum tersebut dinamakan Dewan Hisbah, di al-Jam'iyyah alWasliyyah forum tersebut dinamakan Dewan Fatwa, sementara di MUI (Majlis Ulama Indonesia) forum tersebut dinamakan Komisi Fatwa. $^{47}$

Bahtsul masail yang merupakan aktivitas santri untuk merespon dan memberikan solusi atas berbagai problematika aktual yang muncul dalam kehidupan masyarakat, secara formal pertama kali dilaksanakan pada tahun 1926, beberapa bulan setelah NU didirikan. Tepatnya pada Kongres atau Muktamar I NU, yaitu pada tanggal 21-23 Oktober 926/13-15 Rabi' al-Thâny 1345 di Surabaya. Sejak tahun 1926 sampai 2010 telah diselenggarakan bahtsul masail NU sebanyak 43 kali. Namun ada beberapa bagian hasil bahtsul masail dalam Muktamar yang dokumennya masih belum ditemukan, yaitu Muktamar XVII (1947), XVIII (1950), XIX (1952), XXI (1956), XXII dan XXIV. Dari dokumen yang terlacak, hanya ditemukan 37 kali pelaksanaan bahtsul masail yang

\footnotetext{
${ }^{46}$ Lihat: Ahmad Zahro, Tradisi Intelektual NU; Lajnab Babhthul Masâil 1926-1999 (Yogyakarta: LKiS Pelangi Aksara Yogyakarta, 2004), cet. 1, 68.

${ }^{47}$ Ahmad Zahro, Tradisi Intelektual NU....73-74
} 
menghasilkan 501 keputusan atau fatwa. ${ }^{48}$ Secara garis besar dari 501 keputusan dibagi menjadi tiga bagian, dengan perincian sebagai berikut: sejak tahun 1926 sampai 2010 telah memutuskan 456 keputusan masail al-diniyyah al-waqi'iyyah. Sejak Muktamar NU ke-29 di Tasikmalaya, Rajab 1415/Desember 1994 sampai Muktamar ke32 di Makasar, 7-11 Rabi'ul Akhir 1431/2227 Maret 2010 telah menghasilkan 31 keputusan masail al-diniyyah al-maudlu'iyyah. Dan sejak Munas NU di Surabaya 27-30 Juli 2006 sampai Muktamar ke-32 di Makasar $7-$ 11 Rabi'ul Akhir 1431/22-27 Maret 2010 menghasilkan 14 keputusan masail al-diniyyah al-qanuniyyah. ${ }^{49}$

\section{b. LBM dan Rumusan Metode Ijtihad \\ LBM merupakan forum resmi milik} NU yang mempunyai wewenang untuk menjawab segala permasalahan keagamaan yang dihadapi oleh masyarakat muslim khususnya warga Nahdliyyin. Kegiatan bahtsul masail pada dasarnya merupakan tradisi akademik yang selalu melekat dalam organisasi NU. Bahkan tradisi keilmuan NU banyak terpengaruh oleh hasil keputusan forum ini, karena semua masalah

${ }^{48}$ Bandingkan dengan Ahmad Zahro yang menurut penghitunganya sejak tahun 1926 sampai tahun 1999 telah dilaksanakan 39 kali Bahtsul Masail, namun enam hasil Bahtsul Masail dokumennya belum bisa dilacak sehingga yang ditemukan hanya $33 \mathrm{kali}$ pelksanaan Bahtsul Masail dengan memutuskan 505 keputusan. Lihat Ahmad Zahro, Tradisi intelektual NU.....69

${ }^{49}$ Nahdlatul Ulama, Abkam al-Fuqaha...xvii

${ }^{50}$ Pada kurun waktu 1926 sampai dengan 1940 kegiatan BM dilaksanakan sekali dalam setiap tahun pada muktamar I sampai Muktamar XV. Pada waktu perang dunia II, pelaksanaan BM mengalami ktidakstabilan mengiringi tersendatnya Muktamar, seperti Muktamar XVI dan XVII (1946-1947), Muktamar XVIII dan Muktamar XIX (1950-1951), Muktamar XX dan Muktamar XXI (1954-1956. Begitu juga kegiatan BM yang menyertai Konferensi Besar. Rapat Dewan Partai maupun Musyawarah keagamaan yang masuk, dikaji dan diberikan jawabanya serta hasilnya disebarluaskan ke warganya. Kegiatan ini dilakukan di NU secara berkala dalam kurun waktu tertentu, baik di tingkat Cabang, Wilayah, maupun Pusat. $^{50}$

Biasanya permasalahan yang akan diangkat ke forum BM (bahtsul masail) dimulai dari tingkat ranting (desa). Jika terjadi kemusykilan, maka diangkat ke tingkat Anak Cabang (kecamatan). Jika masih terjadi kemusykilan, maka diangkat ke BM yang lebih tinggi yaitu tingkat Cabang (kabupaten). Jika terjadi mawquf lagi, maka diteruskan ke BM tingkat Wilayah (provinsi). Jika masih terjadi mawquf lagi, maka permasalahan dibawa ke BM tingkat nasional dalam forum BM Muktamar PBNU atau Munas 'Alim Ulama. ${ }^{51}$

Adapun mekanisme penyelesaian masalah yang dilakukan oleh LBM sebagian besar adalah langsung merujuk kepada kitab-kitab mu'tabara ${ }^{52}$ dari kalangan empat mazhab, terutama mazhab Syafi'i. ${ }^{53}$ Sehingga memberikan kesan bahwa BM cenderung kepada penyelesaian masalah dengan cara penerapan harfiyyah (tekstualis) hukum-hukum fikih yang ditetapkan ulama-

Nasional Alim Ulama terselenggara kurang stabil selama kurun waktu 1957 sampai 1979. Selama kegiatan tersebut kegiatan BM hanya terlaksana sebanyak delapan kali. Kemudian pada dekade 1980an dan 1990an kegiatan BM baru dapat berlangsung secara periodik sekali dalam kurun waktu 2-3 tahun secara bergantian antara Muktamar, Munas dan Konferensi Besar. Lihat Ahmad Zahro, Tradisi Intelekual NU...69

${ }^{51}$ Abdul Mughits, kritik Nalar Fiqih Pesantren (Jakarta: Prenada Media Group, 2008), 180

${ }^{52}$ Kitab-kitab mu'tabarah adalah kitab-kitab yang diakui oleh kalangan ahl al-sunnah wa al-jama'ah.

${ }^{5} J$ Jika dilihat hasil bahtsul masail, maka mazhab syafi'i mendominasi keputusan bahtsul masail tersebut. Hal ini terjadi karena tidak terlepas dari kultur Islam Indonesia sendiri yang mayoritas adalah penganut mazhab Syafi'i. 
ulama besar terdahulu. Menurut Rifyal Ka'bah sebagaimana dijelaskan Ahmad Zahro bahwa fenomena ini terjadi karena NU gigih mempertahankan dan menaruh penghormatan yang besar terhadap karya ulama-ulama terdahulu. Hal ini berbeda dengan kaum modernis seperti Muhammadiyah yang cenderung menyelesaikan masalah langsung merujuk kepada al-Qur'an dan Hadits. Bahkan dalam keadaan tertentu dapat menggunakan rasional untuk menyelesaikan suatu masalah. ${ }^{54}$

Seiring dengan perkembangan ilmu pengetahuan dan teknologi serta kritik kemandegan dan kejumudan pemikiran keagamaan, NU melakukan transformasi tradisi bahtsul masail. NU lewat MUNAS Alim Ulama yang dilaksanakan di Bandar Lampung pada tanggal 16-20 Rajab 1412 H./21-25 Januari 1992 M. telah menetapkan prosedur ijtihad yang menjadi pegangan NU dalam merespon berbagai permasalahan yang sedang dihadapi masyarakat akibat dari perkembangan ilmu pengetahuan dan teknologi. Hal ini menunjukan bahwa NU sudah mulai beranjak dari hanya sekedar bermazhab secara qawlî (verbalis) menjadi menerima juga model bermazhab secara manhajî (metodologis). ${ }^{55}$

Prosedur ijtihad yang telah ditetapkan pada MUNAS Alim Ulama di Bandar Lampung, merupakan tindak lanjut dari gagasan-gagasan para pemikir produktif muda NU dalam sebuah forum "ㅂalaqab" (sarasehan) untuk merumuskan kerangka teoritik berfikih yang produktif dan matching bahkan sesuai dengan perkembangan

${ }^{54}$ Ahmad Zahro, Tradisi Intelektual NU...79

${ }^{55}$ M. Ikhsanudin, "Gerakan Pembaharuan Hukum Islam di Indonesia: Studi Model Pembaharuan Metode Penemuan Hukum di Muhammadiyah dan NU" dalam jurnal Mukaddimah, Vol. 16, No. 2, 2010, 162 zaman. Salah satu hasil konkerit dari forum "Halaqah" tersebut adalah munculnya istilah bermadzhab secara manhaji. Pada tahun 1987 dan 1998 atas dukungan K.H. Sahal Mahfudh dan K.H. Imron Hamzah, mereka mempolulerkan istilah tersebut dengan mengadakan seminar di Pondok Pesantren Watu Congol, Muntilan Magelang dengan tema "Telaah Kitab Secara Kontekstual". Pada pertengahan bulan Oktober tahun 1989 diadakan balaqah mengenai "Masa Depan NU” dengan salah satu pembicaranya A. Qodri Azizi, beliau menegaskan perlunya redefinisi bermazhab yang pada akhirnya dicetuskan istilah bermazhab fì al-manhaj (mengikuti metodologinya para imam mujtahid). ${ }^{56}$ Kemudian pada tanggal 26-28 Januari 1990, di kalangan pesantren telah diadakan diskusi untuk mencari metode bahtsul masail yang lebih maju. Hal ini tercermin dalam $\underline{\text { halaqah }}$ di Pondok Pesantren Manba'ul Ma'arif Denanyar Jombang. ${ }^{57}$

Adapun prosedur ijtihad NU sebagaimana yang telah ditetapkan pada MUNAS Bandar Lampung 1992 adalah sebagai berikut: Keputusan bahtsul masail di lingkungan NU dibuat dalam kerangka bermazhab kepada salah satu mazhab empat yang disepakati dan mengutamakan bermazhab secara qawlì dengan menggunakan rujukan dari al-kutub almu'tabarah (kitab-kitab standard yang dianggap realiable). Dalam MUNAS tersebut, diputuskan tentang "Sistem Pengambilan Keputusan Hukum dalam Bahtsul Masail di Lingkungan NU.” Dalam MUNAS ini dibahas dua tema besar.

${ }^{56}$ Mahsun Mahfudz dan Baedhowi, "Mencermati Perkembangan Pemikiran Hukum Islam Di Indonesia; Studi Apresiatif Atas Pemikiran KH. Sahal Mahfudh tentang Fikih Sosial" dalam Jurnal Edisi 7 Vol. IV, April 2008, 59

${ }^{57}$ Ahmad Zahro, Tradisi Intelektual NU...129 
Pertama, tentang sistem pengambilan keputusan hukum yang terperinci dalam tiga pembahasan yaitu prosedur menjawab masalah, hierarkhi dan sifat keputusan dan kerangka analisis masalah. Kedua, tentang prosesi pelaksanaan deduksi hukumnya yang terdiri dari pembahasan prosedur pemilihan qawl/wajah, prosedur ilhâq dan prosedur istinbâth. Dan MUNAS tersebut juga memutuskan penjelasan tentang beberapa istilah terkait dengan sistem pengambilan keputusan hukum dalam Bahtsul Masail dalam uraian ketentuan umum, penjelasan istilah tersebut adalah:

a. Yang dimaksud dengan al-kutub almu'tabarah adalah kitab-kitab tentang ajaran Islam yang sesuai dengan aqidah abl al-sunnab wa al-jamâ'ab (rumusan Muktamar NU ke XXVII) ${ }^{58}$

b. Yang dimaksud dengan bermazhab secara qawli adalah mengikuti pendapat-pendapat yang sudah "jadi” dalam lingkup mazhab tertentu.

c. Yang dimaksud bermazhab secara manhajî adalah bermazhab dengan mengikuti jalan pikiran dan kaidah penetapan hukum yang telah disusun oleh imam mazhab.

d. Yang dimaksud dengan istinbâth adalah mengeluarkan hukum syara' dari dalilnya dengan qawâid usyûliyyah dan qawaid fiqbiyyah.

e. Yang dimaksud dengan qawl adalah pendapat imam mazhab.

\footnotetext{
${ }^{58}$ Menurut penulis, rumusan itu bukan pada Muktamar ke XXVII melainkan pada MUNAS Alim Ulama yang dilaksanakan di Sukorejo Situbondo pada tanggal 6 Rabi'ul Awal 1404 H./21 Desember 1983 M. Dalam rumusan tersebut dijelaskan bahwa al-Kutub al-Mu'tabarah fî Masail al-Diniyyah 'indanâ ialah kitabkitab 'alâ al-Madhabib al-Arba'ah. Perumusan tersebut didasarkan pada kitab; 1) Bughyah al-Mustarsyidîn karya Abdurrahman bin Muhammad Ba'lawi (Indonesia: alHaramain, t.th.), 8. 2) I'ânah al-THâlibîn karya Muhammad Syaththâ al-Dimyâthi (Indonesia: Dar
}

f. Yang dimaksud dengan wajah adalah pendapat ulama mazhab.

g. Yang dimaksud dengan taqrîr jamâ'i adalah adalah upaya secara kolektif untuk menetapkan pilihan terhadap satu diantara beberapa qawl atau wajah.

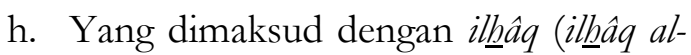
masâil bi nadhâiirihâ) adalah menyamakan hukum suatu kasus atau masalah yang belum dijawab oleh kitab dengan kasus atau masalah serupa

i. Yang telah dijawab oleh kitab (menyamakan dengan pendapat yang sudah "jadi”). ${ }^{59}$

Lebih lanjut, keputusan MUNAS Bandar Lampung tersebut dipertegas dan diperjelas kembali pada MUKTAMAR NU XXXI di Asrama Haji Donohudan Boyolali-Solo Jawa Tengah pada tanggal 1618 Syawal 1425 H./29 Nopember-1 Desember 2004 M. Seperti bermazhab secara qawlî yang hanya dalam lingkup mazhab tertentu, dipertegas menjadi salah satu al-madhâhib al-arba'ah. Bermazhab secara manhajı̂ yang diartikan dengan mengikuti jalan pikiran dan kaidah penetapan hukum yang telah disusun oleh imam mazhab, dipertegas menjadi imam mazhab dari al-madhâbib al-arba'ah. Istilah istinbath yang diartikan mengeluarkan hukum dari dalilnya melalui qawaìd usyûliyyah dan qawaìd fiqbiyyah diperjelas menjadi istinbâth jamâ'i untuk menghindari pelaku tunggal. Qawl dan wajah yang diartikan

Ihya' al-Kutub al-'Arabiyyah, t. th.), jilid I, 17. 3) alFawaiid al-Makkizyah dalam Majmû'ab Sab'ah al-Kutub alMufìdah karya Alawi al-Saqqaf (Mesir: Musythafâ alHalabi, t. th.), 50. Lihat Nahdlatul Ulama, Abkâm alFuqâhâ...386-387

${ }^{59} I \underline{h} \hat{a} q$ merupakan sebuah metode yang hampir mirip dengan metode qiyâs, hanya saja sumber dari metode illhâq bukanlah Al-Qur'an dan Sunnah melainkan al-kutub al-mu'tabarah. Lihat nahdlatul Ulama, Abkâm al-Fuqâhâ...470 
pendapat imam mazhab dan pendapat ulama mazhab, dipersempit lingkupnya sebatas pendapat imam Syafi'i dan ulama mazhab Syafi'i. Begitu juga dengan taqrîr jamâ'i, lingkupnya juga dibatasi hanya menetapkan pilihan terhadap satu di antara beberapa qawl/ wajah dalam mazhab Syafi'i. ${ }^{60}$

MUNAS Alim Ulama Bandar Lampung 1992, selain menjelaskan ketentuan umum, juga menjelaskan tentang petunjuk pelaksanaan pengambilan keputusan. Adapun prosedur pengambilan keputusan adalah sebagai berikut:

1) Prosedur Pemilihan Qawl/Wajah

a) Ketika dijumpai beberapa qaul/wajah (pendapat)dalam satu masalah yang sama, maka dilakukan usaha memilih salah satu pendapat.

b) Pemilihan salah satu pendapat dilakukan dengan tata urutan sebagai berikut:

(1) Dengan mengambil pendapat yang lebih mashlabah dan atau yang lebih kuat.

(2) Sedapat mungkin dengan melaksanakan ketentuan Muktamar NU ke-I, bahwa perbedaan pendapat diselesaikan dengan memilih:

(a) Pendapat yang disepakati oleh alSyaykhân (al-Nawâwy dan al-Râfi'y)

(b) Pendapat yang dipegangi oleh alNawâwy saja

(c) Pendapat yang dipegangi oleh alRafi'y saja

(d) Pendapat yang didukung oleh mayoritas ulama

(e) Pendapat ulama terpandai

(f) Pendapat ulama yang paling warấ

\footnotetext{
${ }^{60}$ Lihat Nahdlatul Ulama, Ahkâm alFuqâbâ...846

${ }^{61}$ Lihat Nahdlatul Ulama, Abkâm alFuqâhâ...472-473

${ }^{62}$ Menjawab permasalahan fikih dengan merujuk pendapat tunggal pada hakikatnya hampir tidak ada,
}

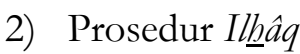

Dalam hal ketika suatu masalah atau kasus belum dipecahkan dalam kitab, maka masalah atau kasus tersebut diselesaikan

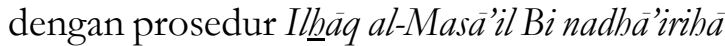
(mempersamakan hukum suatu kasus yang belum ada ketentuan hukumnya dengan kasus yang mirip yang telah ada ketentuan hukumnya dalam kitab fikih) secara jamâ'i (kolektif).

Illhâq dilakukan dengan memperhatikan mulhaq bih (kasus yang telah ada ketentuan hukumnya dalam kitab-kitab fikih), mulbaq ilayh (kasus yang hendak dicari hukumnya atau dipersamakan hukumnya) dan wajh al-ill $\underline{a} q$ (sifat yang mempertemukan antara mulhaq bih dengan mulbaq ilayb) oleh para mulbiq (ulama penggali hukum) yang ahli.

\section{3) Prosedur Istinbâth}

Dalam hal ketika tak mungkin dilakukan illhâq karena tidak adanya mulhaq bih dan wajh al-ilhāq (sisi persamaannya) sama sekali di dalam kitab, maka dilakukan istinbâth secara jamâ'i, yaitu dengan mempraktekkan qawäid usyüliyyah dan qawäid fiqbiyyah oleh para ahlinya. ${ }^{61}$

Dari uraian tersebut, dapat disimpulkan bahwa sistem pengambilan keputusan dalam bahtsul masail Nahdlatul Ulama dirumuskan dalam tiga prosedur. Pertama, prosedur taqrîr jamâ'i, ${ }^{62}$ (penetapan hukum secara kolektif). Taqrîr jamâ'i merupakan upaya secara kolektif untuk menetapkan pilihan terhadap satu diantara beberapa qawl atau wajah, dengan cara

kecuali jika sudah menjadi ijmâ'. Ini berkaitan dengan pemahaman fikih yang berdasarkan dalil âm maka sebagai konsekuwensinya akan melahirkan keputusan dan pemikiran ganda, dua, tiga dan seterusnya. 
permasalahan dicarikan jawabanya yang terdapat dalam al-kutub al-mu'tabarah. Dengan demikian, taqrîr jamâ'i pada dasarnya hanyalah menetapkan saja apa yang sudah ada dalam al-kutub al-mu'tabarah. Kemungkinan, ini disebabkan oleh pandangan yang menjadi keyakinan mereka bahwa apa yang sudah menjadi keputusan para ulama baik qawl atau wajah dianggap selalu memiliki relevansi dengan konteks kehidupan masa kini dan bisa digunakan tanpa ada kritikan. Qawl atau wajah yang terdapat dalam al-kutub al-mu'tabarah dianggap sebagai kata final.

Lebih lanjut, sistem pengambilan keputusan bahtsul masail NU yang mengikuti cara baku yang telah disepakati dikalangan ulama NU, yang telah memberikan alternative pilihan yang disusun secara hierarkis, memberikan kesan bahwa keputusan ini Syafi'i sentris. Cara baku yang telah ditetapkan ulama NU tersebut adalah pertama, pendapat yang disepakati oleh alSyaykhân. Kedua, pendapat yang dipegangi oleh imam Nawawî saja. Ketiga, pendapat yang dipegangi oleh imam Râfi'î saja. Keempat, pendapat yang didukung oleh mayoritas ulama. Kelima, pendapat ulama terpandai dan keenam, pendapat ulama yang paling warâ.' Ada beberapa alasan yang melatarbelakangi kenapa imam Nawawî didahulukan atas imam Râfî̀ sebagaimana yang terjadi atas Ibn $\mathrm{H}$ \{ajar yang lebih diutamakan dari pada imam al-Ramlî. Pertama, berdasarkan pertimbangan penampilan karya ilmiahnya yang a $\underline{b s a n}$ (lebih berbobot) dan 'alimnya orang itu. ${ }^{63}$ Kedua, Nawawî dikenal sebagai mubarrir (penyeleksi) mazhab Syafi'i, di tangan ulama inilah pemikiran-pemikiran imam Syafi'i terseleksi.
Ketiga, Nawawî selain faqîh (ahli fikih) juga dipandang sebagai mubaddith 'âqil (ahli Hadits yang cerdas) sedangkan Râfi'î hanya faqî̉ (ahli fikih). Nawawi mempunyai banyak karya dalam bidang Hadits, di antaranya alManhâj, Syarh al-Muslim, al-Adbkâr, Arba'în al-

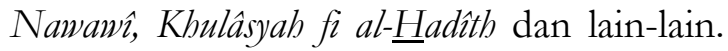
Keempat, Nawawi memiliki kecenderungan sikap asketis lebih tinggi dari Râfi'î. ${ }^{64}$

Kedua, prosedur ilhâq al-masâil bi nadhâ'irihâ. Prosedur ini digunakan untuk menggantikan istilah qiyas, yang menurut pandangan NU tidak layak dan tidak patut dilakukan, karena qiyâs merupakan suatu kompetensi yang hanya dimiliki oleh seorang mujtahid. Hal ini menunjukan atas sikap kehati-hatian NU agar tidak terjebak dalam melakukan kajian-kajian langsung terhadap sumber-sumber ajaran Islam yakni al-Qur'an dan Sunnah.

Dalam illkâq yang mesti diperhatikan adalah harus adanya mulbaq bih, mulbaq ilayh dan wajah ilhâq. Il $\underline{h} a$ adalah mempersamakan persoalan fikih yang belum ditemukan jawabanya dalam kitab secara tekstual dengan persoalan yang sudah ada jawabanya. Dalam praktiknya, metode ilhâq menggunakan prosedur dan persyaratan mirip qiyâs, hanya saja, dalam illhâq yang dijadikan mulhaq bib adalah pendapat atau qawl/wajah para ulama yang terdapat dalam al-kutub al-mu'tabarat sedangkan dalam qiyâs mulbaq bih adalah sumber utama ajaran Islam yaitu Al-Qur'an dan Sunnah.

Ketiga, prosedur istinbath. Istinbâth merupakan metode terakhir yang digunakan oleh bahtsul masail NU, manakala pertanyaan atau kasus tidak terdapat jawabanya (sama sekali) dalam kitab-kitab standart (al-kutub al-mu'tabarah) baik berupa

\footnotetext{
${ }^{64}$ Husein Muhammad, "Tradisi Istinbat Hukum
} $N U^{\prime}, \ldots 29$ 
qawl atau wajah, dan tidak memungkinkan untuk melakukan ill $\underline{a} q$, maka langkah yang dilakukan adalah istinbâth secara kolektif dengan mepraktikkan qawâid usyûliyyah dan qawaid fiqhiyyah sebagaimana yang telah dirumuskan oleh para mujtahid terdahulu. Dengan demikian, maka produk hukum yang dihasilkan merupakan hasil ijtihad ulamaulama NU atas nasy-nasy al-Qur'an dan Sunnah yang sesuai dengan prinsip-prinsip ijtihad yang digunakan oleh para mujtahid terdahulu.

Jadi, istinbâth merupakan langkah dan alternative terakhir dalam bahtsul masail. Maksudnya istinbâth dapat digunakan manakala suatu masalah atau kasus tidak terdapat jawabanya dalam al-kutub almu'tabarah sehingga tidak dapat dilakukan pemilihan qawl atau wajab dan tidak memungkinkan untuk dilakukan ilhâq karena tidak adanya mulhaq bih dan wajah illhâq. Istinbath dilakukan dengan cara kolektif dengan mengaplikasikan qawaìd usyûliyyah dan qawaiid fiqhiyyah oleh para ahlinya.

\section{Kesimpulan}

NU sebagai ormas Islam yang berhaluan abl al-sunnab wa al-jamâ'ab dalam menjalankan ajaran Islam berpangkal pada tiga panutan yaitu dalam bertauhid mengikuti paham Abu Hasan al-Asy'ari dan Abu Mansur al-Maturidi; dalam berfikih mengikuti salah satu mazhab fikih empat yang terkenal dengan sebutan al-madhâbib alarba'ah (Hanafi, Maliki, Syâfi'i, dan Hanbali); dan dalam bertasawuf mengikuti cara yang ditetapkan dan dirumuskan al-Junaid alBaghdadi dan Abu Hamid Muhammad bin Muhammad al-Ghazali.

Sedangkan tradisi intelektual NU diwadahi dalam forum Bahtsul Masail dengan menggunakan kitab kuning yang diakui (al-kutub al-mu'tabarah) sebagai rujukannya. Adapun metode yang digunakan dalam risetnya pertama taqrir jamâ'i (penetapan hukum secara kolektif). Taqrîr jamâ'i ini merupakan suatu upaya secara kolektif untuk menetapkan pilihan terhadap satu di antara beberapa qawl atau wajah, dengan cara permasalahan dicarikan jawabanya yang terdapat dalam al-kutub almu'tabarah.

Kedua ilhâq al-masâil bi nadhâirihâ, prosedur ini digunakan untuk menggantikan istilah qiyas. Il $\underline{b} \hat{q} q$ adalah mempersamakan persoalan fikih yang belum ditemukan jawabanya dalam kitab secara tekstual dengan persoalan yang sudah ada jawabanya dalam kitab. Dalam praktiknya, metode illhâq menggunakan prosedur dan persyaratan mirip qiyâs, hanya saja, dalam illbâq yang dijadikan mulhaq bih adalah pendapat atau qawl/wajah para ulama yang terdapat dalam al-kutub al-mu'tabarat sedangkan dalam qiyâs mulhaq bib adalah sumber utama ajaran Islam yaitu Al-Qur'an dan Sunnah.

Ketiga istinbath yang merupakan metode terakhir yang digunakan oleh bahtsul masail NU, manakala pertanyaan atau kasus tidak terdapat jawabanya (sama sekali) dalam kitab-kitab standart (al-kutub al-mu'tabarab) baik berupa qawl atau wajah, dan tidak memungkinkan untuk melakukan ilbâa, maka langkah yang dilakukan adalah istinbath secara kolektif dengan mepraktikkan qawaìd usyâliyyah dan qawaid fiqhiyyah sebagaimana yang telah dirumuskan oleh para mujtahid terdahulu.

\section{Daftar Pustaka}

Arifi, Ahmad. "Pergulatan Fiqh dalam fikih Nahdlatul Ulama: Analisis Paradigma atas fikih Tradisi”. Disertasi. Yogyakarta: PPs UIN Yogyakarta, 2007 
Asy'ari, Hasyîm. Ibyâ' 'Amal al-Fud\}âla; Muqaddimah Anggaran Dasar NU, Kendal: tp., 1969

Asy'ari, M. Hasyim. Risalah Abl Assunnah wa al-Jamäah: fi Hadith, al-Mauta wa Asyrāt, as-Säah wa Bayān Mafbū asSunnah wa al-Bid'ah. Jombang: Maktabah at-Turas al-Islami bi Ma'had Terbuireng, $1418 \mathrm{H}$

Bruinessen, Martin Van. Kitab Kuning, Pesantren dan Tarekat: Tradisi-tradisi Islam di Indonesia. Bandung: Mizan, 1996

Bruinessen, Martin Van. Traditionalist Muslims in A Modernizing World: The Nabd\}atul Ulama and Indonesia's New Order Politics, Factional Conflict and The Search for A New Discourse, Pent. Farid Wajidi, Yogyakarta: LkiS, Cet: IV, $2004 \backslash \backslash \backslash$

Dhofier, Zamakhsyari. Tradisi Pesantren Studi tentang Pandangan Hidup Kyai. Jakarta: LP3ES, 1994

Dlofier, Zamakhsyari. Tradisi Pesantren, Studi Tentang Pandangan Hidup Kiyai. Jakarta: LP3ES, 1984

DZ, Abdul Mun'in. "Bahtsul Masail Tradisi Akademik Muslim Tradisionalis", dalam Jurnal Gerbang, vol. 12, tahun 2002

Hosen, Nadirsyah. "Nahdlatul Ulama and Collective Ijtihad" dalam journal New Zealand Journal of Asian Studies 6, 1 . Juni 20045

Iqbal, Muhammad. Hukum Islam Indonesia Modern: Dinamika Pemikiran dari Fikih Klasik ke Fikih Indonesia. Tangerang: Gaya Media Pratama, 2009

Karamali, Syaista P. Ali and Fiona DunneSource, "The Ijtihad Controversy", dalam Journal Arab Law Quarterly, Vol. 9, No. 3 (1994), pp. 238-257 Publisyed by: BRILL
Stable

URL: http://www.jstor.org/stable/33815 68. Diakses pada tanggal 25 Mei 2014 al-Khatib, Muhammad 'Ajaj. Ushûl al-Hadîth Ulûmuh wa Musythalabuh, Beirut: Dar al-Fikr, 2006 al-Hasyimiy, Muhamad Ma'syum Zainy. Pengantar Memahami Nadham Baiqûniyyah.Jombang: Darul Hikmah Jombang, 2008

M. Ikhsanudin, "Gerakan Pembaharuan Hukum Islam di Indonesia: Studi Model Pembaharuan Metode Penemuan Hukum di Muhammadiyah dan NU" dalam jurnal Mukaddimah, Vol. 16, No. 2, 2010

M.B. Hooker, Islam Marhab Indonesia: Fatwafatwa dan perubahan Sosial, terj. Iding Rassyidin Hasan. Jakara: Teraju, 2002

Ma'syum, Saifullah. Karisma Ulama, Kehidupan Ringkas 26 Tokoh NU. Bandung: Mizan, 1998

Mahfudh, Muhammad Sahal. "Bahtsul Masail dan Istinbath Hukum NU: Sebuah catatan pendek" dalam A. Ma'ruf Asrori dan Ahmad Muntaha (eds), Abkâm al-Fuqâhâ: Solusi Problematika Aktual Hukum Islam Keputusan Muktamar, Munas dan Konbes 1926-2010. Surabaya: Khalista dan Lajnah Ta'lif Wan Nasyr (LTN) PBNU, 2011

Mahfudh, Muhammad Sahal. Nuansa Fikih Sosial. Yogyakarta: LKiS, 1994

Mahsun. dan Baedhowi, "Mencermati Perkembangan Pemikiran Hukum Islam Di Indonesia; Studi Apresiatif Atas Pemikiran KH. Sahal Mahfudh tentang Fikih Sosial" dalam Jurnal Edisi 7 Vol. IV, April 2008

Makdisi, George. "The Sunni Revival", dalam Islamic Ciilization 950-1150 
(Papers on Islamic History III), ed. D.H. Ricards. Oxford: Cassier-The Near East Center Unviersity of Pannsylvania, 1973

Muchtar , Masyhudi. Dkk. Aswaja AnNabdliyyah: Ajaran Ablussunnah wal jama'ah yang berlaku di lingkungan Nabdlatul Ulama. Surabaya: Khalista dan Lajnah Ta'lif Wa al-Nasyr (LTN) NU Jawa Timur, 2007

Mughits, Abdul. kritik Nalar Fiqih Pesantren. Jakarta: Prenada Media Group, 2008

Muhammad, Husein. "Tradisi Isinbat Hukum NU: Sebuah Kritik", dalam M. Imdadun Rahmat (ed), Kritik Nalar Fiqib NU: Transformasi Paradigma Babtsul Masail. Jakarta: LAKPESDAM NU, 2002

Mustofa, Misbah. Anda Ablussunnab? Anda Bermadzhab? Tuban: al-Misbah, 2006 Nahd\}atul Ulama. Abkâm al-Fuqâhâ; Solusi Problematika Aktual Hukum Islam, Keputusan Muktamar, Munas dan Konbes Nabd\}atul Ulama 1926-2010. Surabaya: Khalista dan Lajnah Ta'lif Wa Al-Nasyr, 2011.

Nasution, Harun. Teologi Islam: Aliran-Aliran, Sejarah Analisa dan Perbandingan. Jakarta: Penerbit Universitas Indonesia, 1986.

Al-Syâthibî. Al-Muawafaqat Fi Ushul alSyariah, Beirut: Dâr al-Kutub alIlmiyah, Juz II, 2003

Wahid, Abdurrahman. Prisma Pemikiran Gus Dur. Yogyakarta: LKiS, 2000

Winarno. "Pergesaran Ijtihad dalam Bahtsul Masail Nahdlatul Ulama”. Resensi buku "Dinamika Ijtihad NU" penulis Imam Yahya, penerbit: Semarang: Walisongo Press, 2009. Dalam jurnal SUHUF, Vol. 21, No. 2, Nopember 2009 ,
Yahya, Imam. Dinamika Ijtihad NU, Semarang: Walisongo Press, 2009

Zahro, Ahamad. Tradisi Intelektual NU; Lajnah Bahtsul Masail 1926-1999 (Yogyakarta: LKiS, 2004

Zahro, Ahmad. Tradisi Intelektual NU; Lajnah Babthul Masâil 1926-1999. Yogyakarta: LKiS Pelangi Aksara Yogyakarta, 2004 